\title{
Aldehyde Dehydrogenase 1 Family
}

National Cancer Institute

\section{Source}

National Cancer Institute. Aldehyde Dehydrogenase 1 Family. NCI Thesaurus. Code C129434.

A polymorphic family of intracellular enzymes that catalyze the oxidation of aldehydes and yield carboxylic acids. High aldehyde dehydrogenase 1 activity may indicate the presence of stem cells or cancer stem cells (CSC) in a sample. 